\title{
QUESTÕES CONTROVERTIDAS SOBRE A RESPONSABILIDADE DO SÓCIO E DO EX-SÓCIO NO PROCESSO DO TRABALHO
}

\author{
SHARED RESPONSIBILITIES AMONG PARTNERS, OWNERS AND CORPORATIONS IN BRAZILIAN \\ LABOUR PROCEDURE
}

Homero Batista Mateus da Silva*

\begin{abstract}
Resumo:
O presente estudo objetiva traçar um panorama atual sobre a responsabilidade subsidiária dos sócios nas hipóteses em que, em fase de execução no processo do trabalho, os bens da pessoa jurídica sejam insuficientes para satisfação dos créditos. A matéria propriamente dita nada tem de nova, remontando aos primeiros decretos que regulamentavam as sociedades por quotas de responsabilidade limitada, passando pelo Código Civil de 1916 e de 2002. Todavia, o estudo procurará demonstrar que, aos poucos, foi sendo abandonada a exigência de comprovação dos amplos poderes de mando e gestão do sócio, ou seu exercício abusivo, assim como foi aumentando simultaneamente a preocupação com a figura dos ex-sócios, objeto de investigação especial no presente trabalho. O artigo sustentará a tese de que essa maior liberdade na interpretação da responsabilidade de sócios e ex-sócios se deve, sobretudo, (a) à promiscuidade patrimonial verificada entre pessoas jurídicas e pessoas naturais, na sociedade brasileira, (b) às altíssimas taxas de encerramento das pessoas jurídicas logo no primeiro ou no segundo ano de existência e (c) à elevada rotatividade de sócios nos estatutos da empresa.
\end{abstract}

Palavras-chave: Processo do trabalho. Fase de execução. Responsabilidade patrimonial. Responsabilidade subsidiária. Sócios. Ex-sócios. Desconsideração da personalidade jurídica. Sociedade limitada. Sociedade anônima.

\begin{abstract}
:
The following paper aims to showcase a broad view about the responsibilities of partners and owners in those situations concerning the end of the company, mainly in the labour procedure. It is true that this subject is far from being a brand new one. Throughout the century, there have been acts and decrees adressing the companies and there shared responsibilities, including Brazilian Civil Codes both in 1916 e de 2002. However, this survey sustains that, gradually, the burden of proof concerning high levels of authority and management has been softned, as well as much more attention has been paid to the responsibilities of ex-owners. The reasons of this movement seem to lie mainly on: (a) the difficulty to separate, on clear basis, the personal and the corporate patrimony in Brazilian society; (b) the increadibly highamount of closing corporations in the very first year of their existence, and, last but not least, (c) the enormous turn over among partners and owners.
\end{abstract}

\footnotetext{
Homero Batista Mateus da Silva é Mestre e Doutor em Direito do Trabalho pela Universidade de São Paulo. Professor doutor do Departamento de Direito do Trabalho e Seguridade Social da Universidade de São Paulo desde 19.06.2009. Juiz do Trabalho desde 18.07.1996, atualmente titular da $88^{\mathrm{a}}$ Vara do Trabalho de São Paulo.
} 
Keywords: Labour procedure. Final enforcing power. Responsibility. Coresponsibility. Partners. Ex-partners. Disregard of legal entity. Incorporated company.

1. Avanço histórico da desconsideração da personalidade jurídica

É preciso notar inicialmente que a técnica da desconsideração da personalidade jurídica sofreu numerosas alterações desde seu conceito original e ainda passa por alterações profundas, pondo em xeque diversas concepções. O momento está mais para a perplexidade do que para a previsibilidade dos comportamentos, ou, o que é pior, mais para a insegurança das relações jurídicas do que para a precisão dos limites da responsabilidade patrimonial dos sócios quotistas de pessoa jurídica.

Os problemas foram ainda mais exacerbados com as teorias favoráveis ao avanço de penhora sobre o patrimônio de ex-sócios, que ficam igualmente coresponsáveis tanto quanto os atuais sócios; e, ainda, com as discussões sobre a aplicação extensiva dessas técnicas também para empresas que não foram constituídas sob a forma de sociedade por quotas de responsabilidade limitada, isto é, se poderíamos também pensar em desconsideração da personalidade de uma sociedade anônima ou, a extremo, se poderíamos pensar na desconsideração de um ente despersonalizado, como um condomínio. Clubes recreativos, agremiações culturais, casas de caridade e times de futebol entram simultaneamente na lista das entidades sujeitas à invasão patrimonial de seus dirigentes. A matéria, como se vê, é assombrosa.

A fim de se delinear o atual estágio da desconsideração da personalidade jurídica, cumpre lembrar que o conceito data do século XIX, em que a jurisprudência norte-americana demarcou, em célebre acórdão de 1809, a separação entre o patrimônio da pessoa jurídica, de um lado, e o patrimônio das pessoas naturais que a compõem, de outro lado, não estando os credores autorizados, de antemão, a avançarem sobre essas se ainda não exauriram o patrimônio daquela. ${ }^{1}$ A descrição histórica já foi esmiuçada por diversos tratadistas, sendo suficiente que aqui se mencione o artigo seminal de Rubens Requião, que vem sendo republicado desde sua primeira aparição em $1969{ }^{2}$

No ordenamento brasileiro, o assunto era normalmente enfocado à luz das primeiras normas sobre organização das sociedades comerciais, notadamente o Decreto n.

FERREIRA, Luiz Eduardo Martins. Desconsideração da personalidade jurídica: uso e abuso. Revista da Escola Nacional da Magistratura. Brasília. v. 2. n. 3. p. 129. abr. 2007.

2 REQUIÃO, Rubens. Abuso de direito e fraude através da personalidade jurídica. Revista dos Tribunais. São Paulo. v. 58. n. 410. p.12-24. dez. 1969. Por exemplo, republicação no mesmo periódico em 2002: Revista dos Tribunais. São Paulo. v. 91. n. 803. p. 751-764. set. 2002. O autor dedicou bastante energia ao tema, merecendo referência igualmente outros trabalhos. REQUIÃO, Rubens. Abuso de direito e fraude através da personalidade jurídica. In: Aspectos modernos de direito comercial: estudos e pareceres. São Paulo: Saraiva, 1977. 
3.708, de 10 de janeiro de 1919, antiga Lei das Sociedades por Quotas de Responsabilidade Limitada, revogado tacitamente pelo Código Civil de 2002. O art. 10 daquele Decreto tinha redação mais severa e somente acenava com invasão patrimonial do sócio-gerente, e, ainda assim, desde que comprovado seu abuso no exercício dos poderes de mando e gestão. A depender do nível de exigência dessa comprovação e dada a baixíssima aptidão do credor para fazer esta prova, logo se percebe o reduzido desenvolvimento que o conceito apresentou.

O Decreto n. 3.708/1919 resistiu bravamente por quase um século, enfrentando nada menos do que cinco novas Constituições e incontáveis alterações da lei ordinária, mas veio a perder quase toda força no período que vai de 1990, ano da promulgação do Código de Defesa do Consumidor, a 2002, ano da promulgação do Código Civil de 2002. ${ }^{3}$ Se não, vejamos.

$\mathrm{O}$ art. 28 do Código de Defesa do Consumidor ${ }^{4}$ imprimiu uma dinâmica mais extensa para a desconsideração da personalidade jurídica, seja no número de sócios passíveis de serem alcançados, porque não faz referência apenas ao sócio-gerente, quanto no número de hipóteses válidas, porque não se atém aos casos de má-fé. A tipologia adotada pelo art. 28 inclui "abuso de direito, excesso de poder, infração da lei, fato ou ato ilícito ou violação dos estatutos ou contrato social".

Investiu-se grande energia para se saber se o art. 28 do Código de Defesa do Consumidor era aplicável subsidiariamente ao processo do trabalho, dada a dificuldade de se lidar com a norma aberta do art. 769 da Consolidação das Leis do Trabalho, que autoriza a aplicação do direito processual comum, sem oferecer maiores detalhes, e dada a controvérsia sobre o grau de semelhança que podemos enxergar entre a vulnerabilidade dos consumidores, numa relação de consumo, e dos empregados, numa relação de trabalho.

Quando a balança parecia se inclinar favoravelmente à aplicação da norma consumerista ao processo do trabalho, o tema foi quase todo abandonado pela superveniência do art. 50 do Código Civil de 2002, ainda mais abrangente, mais incisivo e sem necessidade de grande esforço hermenêutico para aportar ao direito do trabalho ou ao processo do trabalho, agora com o reforço da via expressa do artigo $8^{\circ}$ da Consolidação das Leis do Trabalho. ${ }^{5}$

\footnotetext{
3 A respeito dos impactos do Código Civil de 2002 sobre a desconsideração da personalidade jurídica foram produzidos diversos estudos, mas a amplitude do artigo 50 ainda parece sob investigação. Ver, dentre outros, XAVIER, José Tadeu Neves. A teoria da desconsideração da pessoa jurídica no novo Código Civil. Revista Forense. Rio de Janeiro. a. 101. v. 379. p. 143-155.

$4 \quad$ Artigo 28 da Lei 8.078, de 11 de setembro de 1990: “O juiz poderá desconsiderar a personalidade jurídica da sociedade quando, em detrimento do consumidor, houver abuso de direito, excesso de poder, infração da lei, fato ou ato ilícito ou violação dos estatutos ou contrato social. A desconsideração também será efetivada quando houver falência, estado de insolvência, encerramento ou inatividade da pessoa jurídica provocados por má administração".

5 Art. $8^{\circ}$ da Consolidação das Leis do Trabalho de 1943: “
} 
O art. 50 do Código Civil de $2002^{6}$ ampliou consideravelmente a tipologia porque, além de fazer referência aos tradicionais casos de abuso de poder e desvio de finalidade, ousou acrescentar a "confusão patrimonial": atingiu em cheio um tema até então tratado com superficialidade. Paralelamente à novidade da confusão patrimonial, o artigo 50 também recebe o mérito de ser pioneiro no conceito de invasão patrimonial dos sócios sem necessidade de desconsideração patrimonial - algo como uma ineficácia momentânea da personalidade jurídica, a fim de se dar prosseguimento à captura de um bem que não deveria estar em nome da pessoa natural, retomando-se, ato contínuo, o curso natural da pessoa jurídica.

Confusão patrimonial e ineficácia momentânea da personalidade jurídica são dois assuntos da mais alta importância e que merecerão destaque como fundamento das principais conclusões deste trabalho.

Fábio Konder Comparato observa que caiu por terra a necessidade de comprovação de culpa ou dolo do sócio, nascendo o conceito de culpa presumida, por não ter a pessoa natural impedido que a lesão fosse perpetrada pela pessoa jurídica. $\mathrm{O}$ eminente comercialista chama a atenção, ainda, para o fato de que a responsabilidade, doravante, reside no poder de controle - assim entendido a simples participação societária - e não mais no poder de gestão - tal como se depreendia do Decreto n. 3.708/1919, que falava em responsabilidade apenas do sócio-gerente. ${ }^{7}$

Não tardou para se instalar o debate acerca do endurecimento excessivo proposto pelo art. 50 - especialmente a culpa presumida, o alcance a qualquer pessoa natural, ainda que não tenha exercido poder de gestão, e a desnecessidade de esgotamento patrimonial da pessoa jurídica para se alcançarem os bens da pessoa física, dentro da tônica da confusão patrimonial. ${ }^{8}$ A repercussão do art. 50 do Código Civil de 2002 é tão expressiva que já existem estudos a respeito dos malefícios que o dispositivo pode causar sobre a viabilidade das sociedades comerciais. ${ }^{9}$

Vale lembrar que no intervalo entre o Código de Defesa do Consumidor e o Código Civil, houve, também, alguns marcos legislativos sobre a desconsideração

$6 \quad$ Art. 50 do Código Civil de 2002: "Em caso de abuso da personalidade jurídica, caracterizado pelo desvio de finalidade, ou pela confusão patrimonial, pode o juiz decidir, a requerimento da parte, ou do Ministério Público quando lhe couber intervir no processo, que os efeitos de certas e determinadas relações de obrigações sejam estendidos aos bens particulares dos administradores ou sócios da pessoa jurídica".

7 Renato Saraiva afirma que o Tribunal Superior do Trabalho tem aplicado a teoria da penetração de forma ampla, sem necessidade de "comprovação de existência de fraude, simulação ou desvio de finalidade". Cita acórdãos para justificar sua afirmação. SARAIVA, Renato. Curso de direito processual do trabalho. São Paulo: Método, 2005. p. 545.

8 MARIANI, Irineu. Responsabilidade civil dos sócios e dos administradores de sociedades empresárias (à luz do novo Código Civil). Revista dos Tribunais. São Paulo. v. 94. n. 834. abr. 2005. p. 58-73.

9 TADDEI, Marcelo Gazzi. O desafio da manutenção do sucesso da sociedade limitada na vigência do novo Código Civil. Jus Navigandi. Disponível em: $<$ http://jus2.uol.com.br/doutrina/texto.asp?id=5106>. Acesso em: 4 maio 2011. 
da personalidade jurídica, como o art. 18 da Lei n. 8.884, de 11 de junho de 1994, que dispõe sobre a prevenção e repressão às infrações contra a ordem econômica. ${ }^{10}$ José Elias Alvarenga de Pádua, ${ }^{11}$ em estudo minucioso sobre o tema, cita, ainda, a desconsideração da personalidade jurídica cunhada no artigo $4^{\circ}$ da Lei dos Crimes Ambientais. ${ }^{12}$

Considerando-se que o presente estudo, todavia, destina-se prioritariamente a entender a responsabilidade dos sócios no processo do trabalho, esse panorama histórico é suficiente para se enfrentar aquela que talvez seja a questão mais tormentosa sobre a desconsideração da personalidade jurídica atualmente: a responsabilidade do ex-sócio.

2. Dificuldades práticas de se absolverem liminarmente todos os ex-sócios da pessoa jurídica

Para o senso comum, provavelmente a solução mais justa e objetiva seria a absolvição liminar de todos os ex-sócios da pessoa jurídica, por ela respondendo quem estiver à frente da administração quando da cobrança da fatura.

Ademais, não parece razoável supor que o adquirente de um estabelecimento ignore suas condições financeiras: normalmente o comprador tem acesso à escrita contábil, avalia os riscos, pede abatimento no preço em caso de pendências volumosas e pode cancelar a negociação se vislumbrar entraves ou embaraços desproporcionais às vantagens da transação. Sabe-se que, a depender do patamar da negociação, tornou-se comum o comprador depositar o preço em conta vinculada, mas ainda não disponibilizada diretamente ao vendedor, até que se apure, com mais vagar, a real dimensão do passivo assim entendida a somatória das dívidas consolidadas e, também, das dívidas meramente reivindicadas.

Aliás, as grandes transações comerciais, que envolvem capital internacional, costumam levar em consideração também os prazos prescricionais, porque, como se sabe, o passivo de uma empresa não deve ser medido apenas pela dívida conhecida, mas, também, pela dívida que pode vir a ser objeto de pretensão judicial.

De boa-fé, um empreendedor já tem, ao menos, uma noção de quantas transações pretéritas dispunham de potencial de questionamento em juízo, incluindo-se contratos com fornecedores, clientes e trabalhadores, além do planejamento tributário.

$10 \quad$ Art. 18 da Lei n. 8.884, de 11 de junho de 1994: “A personalidade jurídica do responsável por infração da ordem econômica poderá ser desconsiderada quando houver da parte deste abuso de direito, excesso de poder, infração da lei, fato ou ato ilícito ou violação dos estatutos ou contrato social. A desconsideração também será efetivada quando houver falência, estado de insolvência, encerramento ou inatividade da pessoa jurídica provocados por má administração".

11 PÁDUA, José Elias Alvarenga de. Responsabilidade patrimonial dos sócios e dos eventuais ex-sócios pelas obrigações trabalhistas contraídas pela sociedade. Revista de Direito Mercantil, Industrial, Econômico e Financeiro. São Paulo. v. XLVI. n. 148. p. 59-87. out. 2007.

12 Art. $4^{\circ}$ da Lei n. 9.605/1998: "Poderá ser desconsiderada a pessoa jurídica sempre que sua personalidade for obstáculo ao ressarcimento de prejuízos causados à qualidade do meio ambiente". 
Mas, ao final, somente a consolidação dos principais prazos prescricionais e decadenciais poderá lhe oferecer maior segurança às relações jurídicas. Dentro desse raciocínio, há algumas transações de vulto em que o adquirente quita, digamos, 50\% do valor ajustado e segura a outra metade para pagamento em dois anos, por exemplo, se quiser ver escoados os principais prazos trabalhistas, ou cinco anos, se quiser incluir os prazos tributários gerais. Essa prática já não é mais uma raridade.

Ocorre que essa prática e esses comentários somente reforçariam o entendimento singelo de que o sócio presente é o único e solitário responsável por todas as dívidas, tanto aquelas que ele contraiu em sua administração, quanto aquelas que ele herdou de administrações passadas, mas não é esse o entendimento prevalecente e haveria diversas anomalias se o ordenamento houvesse optado pela imunidade do ex-sócio.

Basta que se afigure um único exemplo: empresário em dificuldades financeiras aliena a pessoa jurídica por um valor simbólico - às vezes, nada mais do que um real - e se livra de todo o passivo trabalhista que ele próprio angariou. A alienação poderia ocorrer até mesmo no curso do processo e não necessariamente seria feita para pessoas idôneas, concentradas nos esforços para reerguer o empreendimento. $\mathrm{O}$ cenário seria desolador.

Provavelmente, alguém se lembraria de estudar o tema sob o enfoque da fraude à execução - quando a alienação é feita com processo judicial já em andamento ou da fraude contra credores - quando o intuito expresso é de minar as forças patrimoniais do devedor para frustrar a satisfação dos credores. Claro que isso sempre poderá ser feito, mas a um custo processual elevado, a depender de provocação e de produção de provas por parte do credor, o qual, aliás, pode vir a sucumbir em sua pretensão, caso não consiga convencer o magistrado de que tenha existido orquestração para livrar do pólo passivo justamente aquele que mais se beneficiou do negócio jurídico. E, afinal, nem sempre a transação será fraudulenta, surgindo enorme dificuldade para se saber quando uma empresa foi alienada para empresários títeres ou quando a alienação foi feita de boa-fé para novos empreendedores.

Some-se a isso a espantosa informação a respeito de pessoas jurídicas especializadas em comprar empreendimentos em dificuldade financeira, com o único propósito, pasmem, de agravar-lhes a situação e encerrar as atividades, mediante falência ou distrato. É a chamada empresa-abutre, que, aos poucos, começa a ser conhecida no sistema brasileiro.

O fato é que a pessoa jurídica no direito brasileiro assumiu uma densidade baixa. Não se nota uma separação idônea entre o patrimônio da pessoa jurídica e aquele da pessoa natural que a compõe. É comum que as contas pessoais do sócio sejam pagas pela pessoa jurídica, assim como a compra de seu carro e dos móveis que guarnecem sua residência, assim como se observa a proliferação de pessoas jurídicas unipessoais, 
constituídas especificamente para a prestação de serviços, escamoteando uma relação que deveria ser puramente trabalhista.

A partir dessas constatações, surge o entendimento de que o sócio se beneficia direta e pessoalmente da prestação de serviços do empregado - isso sem contar aquelas hipóteses em que o empregado da pessoa jurídica é deslocado para prestar serviços particulares para o sócio ou para membros de sua família. Recebe-se com naturalidade essa incumbência e mesmo no âmbito dos trabalhadores parece razoável que o engajamento numa empresa valha tanto para os serviços daquele empreendimento quanto para os serviços particulares das pessoas físicas que o comandam.

Todavia, essa liberdade de circulação entre a esfera empresarial e a esfera familiar produzirá efeitos diretos na execução trabalhista, ou seja, se na época em que comandava a empresa o sócio se comportou como se ela fosse uma extensão de sua personalidade, para fins de pagamentos ou de prestação de serviços, espera-se que também na época em que a dívida for judicialmente cobrada seu patrimônio pessoal seja envolvido tanto quanto o patrimônio da empresa, mesmo que ele já tenha se retirado.

Enfim, parece realmente que ainda está para ser feito o estudo aprofundado da baixa densidade das pessoas jurídicas no Brasil - a promiscuidade entre seu patrimônio e aquele das pessoas naturais integrantes.

Assim sendo, ao invés de partir para um cenário de completa ausência de responsabilidade de sócio retirante, o modelo brasileiro pode ser definido como aquele das responsabilidades compartilhadas, entre o alienante e o adquirente. A expectativa vai no sentido de maior seriedade nas transações e maior zelo quanto ao período de transição.

Nada impede, evidentemente, que os empresários ajustem entre si a forma como serão pagas as dívidas antigas, não sendo incomum que haja cláusula expressa de assunção da responsabilidade integral pelo alienante - caso em que ele pode aumentar o preço da venda, porque assume o passivo - ou, ao revés, assunção de responsabilidade integral pelo adquirente -, caso em que ele certamente conquista um abatimento no preço da transação, dado que a empresa sai depreciada diante de tantos fardos para carregar.

$\mathrm{O}$ que não se pode admitir, todavia, é que o credor fique à mercê dessa negociação, à qual, aliás, ele normalmente não tem acesso. Referidas cláusulas são inoponíveis aos credores. Daí por que a regra do artigo 1.003 do Código Civil de 2002, que se passa a analisar, imprime a natureza de responsabilidade solidária entre os dois empreendedores - o que se retira e o que se estabelece - como regra geral, alheia às discussões inerente à transação. 
3. Importância da aplicação subsidiária do art. 1003 do Código Civil de 2002 ao processo do trabalho

Diante do panorama acima delineado, não surpreende que a jurisprudência trabalhista tenha começado a investir sobre o patrimônio do ex-sócio.

Era relativamente previsível que esse entendimento jurisprudencial começasse a ser construído, diante da imensa quantidade de processos paralisados por falta de pagamento, depósitos ou bens à penhora. O que não se pode tolerar é a profunda insegurança jurídica superveniente, dada a ausência de critérios previamente estabelecidos sobre quais as circunstâncias exatas em que o ex-sócio será acionado e quais suas oportunidades de defesa.

As propostas vão desde a responsabilidade ilimitada do ex-sócio até sua blindagem integral. Para piorar a situação, pode haver muito mais do que uma alteração no quadro de sócios, na constância de um único contrato de trabalho ou na constância de um processo do trabalho. É suficiente imaginar um empregado que tenha permanecido dez anos no mesmo estabelecimento comercial e tenha conhecido, digamos, quatro empregadores diferentes - ou melhor, um único empregador, pessoa jurídica, que passou por quatro sócios proprietários diferentes, em épocas distintas.

Mas a solução mais equilibrada passa pela aplicação ao processo do trabalho do art. 1.003, parágrafo único, do Código Civil, assim redigido: “Até dois anos depois de averbada a modificação do contrato, responde o cedente solidariamente com o cessionário, perante a sociedade e terceiros, pelas obrigações que tinha como sócio".

A norma se apresenta oportuna e tem redação adequada, mas tende a enfrentar algumas complexidades, especialmente: a) a forma da contagem desses dois anos; b) o alcance das expressões cedente e cessionário; c) a restrição aos casos de obrigações antigas, dado o uso do verbo no pretérito imperfeito do modo indicativo.

Se não, vejamos.

O prazo de dois anos não merece censura, por não ser excessivamente longo a ponto de deixar o sócio em estado de permanente perplexidade, nem demasiadamente curto, a ponto de pegar os credores desprevenidos.

O problema reside em saber se os dois anos vão (a) da retirada do sócio até a data do ajuizamento da ação, (b) da retirada do sócio até a citação para pagamento da dívida na fase de execução ou, ainda, (c) da retirada do sócio até a data da efetivação da penhora. As hipóteses podem dar a falsa impressão de ser parecidas, mas representam situações diametralmente opostas.

Na hipótese (a), o sócio deve ficar atento ao ajuizamento de novas ações no biênio seguinte a sua retirada, após o que pode se considerar livre dos encargos supervenientes. É uma hipótese simples, de fácil contagem, e que apenas requer ao sócio o direito de ser informado, pelo adquirente do negócio, se houve recebimento de 
citação judicial. Em caso afirmativo, ele pode ter interesse em acompanhar a demanda, não deixando que o adquirente negligencie o direito de defesa e concorrendo para uma prestação jurisdicional favorável aos interesses do empreendimento. São grandes as chances de poder intervir formalmente no processo, na qualidade de assistente simples, caso não queira atuar apenas informalmente, subsidiando o cessionário com informações e documentos relevantes.

O maior problema da hipótese (a) se encontra no fato de que, conquanto tenham sido computados os dois anos corretamente, o processo tem potencial para se estender por mais cinco, dez ou quinze anos, considerando-se que ele terá de vivenciar toda a fase de conhecimento, inclusive a tramitação recursal, e mais os percalços da fase de execução, abrangendo aí o acertamento dos valores e os procedimentos de citação, penhora e avaliação. Deste modo, a presente hipótese tem uma dimensão muito maior do que dois anos, porque contabiliza o biênio apenas para o início do processo e não para o término do suspense. O sócio retirante nunca ficaria completamente desvencilhado da empresa, assumindo o pesado ônus de acompanhar todo o andamento do processo.

Essa vocação para a eternidade afasta a hipótese (a) da melhor interpretação do art. 1003 do Código Civil de 2002, não sendo razoável supor que o legislador, ao fiar um prazo máximo para a responsabilização do sócio retirante, tenha, ao mesmo tempo, pensado numa forma de esse prazo ser dilatado até o limite da exaustão. Deve-se desconfiar da interpretação jurídica que converge para uma solução fora da finalidade pretendida pela norma, evidentemente.

Cumpre frisar, por fim, que existe uma variação ainda mais ousada para a hipótese (a), que autoriza o avanço sobre os bens do sócio excluído mesmo antes de dois anos do ajuizamento da ação, mas contato que essa ação verse sobre parcelas trabalhistas atinentes à época em que ele estava no comando da empresa.

Não é difícil afigurar um exemplo: o sócio fica de 2000 a 2005 e o empregado fica de 2000 a 2007, é dispensado pelo novo sócio e ajuíza uma ação trabalhista em 2009, respeitando o biênio prescricional e reivindicando horas extras retroativas a 2004, dentro do prazo de cinco anos permitido pelo art. 7º, XXIX, da Constituição Federal de 1988. Obviamente que em 2004 o responsável pela empresa ainda era o sócio que se retirou e é certo que a tese seduz, porque, como dito acima, o sócio se beneficiou diretamente daquelas horas extras e pode inclusive tê-las exigido para fins particulares.

Todavia, a questão deve ser vista com cautela, a fim de não se eternizar o debate: esta ação será ajuizada nada menos do que quatro anos após o desligamento do sócio, numa empresa que continuou regularmente suas atividades e numa transação que já não pode mais ser tachada de fraudulenta após tanto tempo de funcionamento, sem falar no tempo que será gasto na tramitação processual. A se adotar esse entendimento, jamais o sócio retirante poderá ser considerado eximido de sua responsabilidade, enquanto perdurar a existência da empresa. Basta lembrar que, além do prazo prescricional trabalhista, há 
também a aplicação do prazo residual de dez anos do Código Civil, que, para muitos, vale também para as reparações por danos morais e materiais oriundos das relações de emprego.

$\mathrm{Na}$ hipótese (b), o sócio retirante mantém a responsabilidade solidária durante o prazo de dois anos entre sua exclusão e o início da fase de execução, que costuma ser marcado formalmente pelo mandado de citação, penhora e avaliação.

A hipótese tem como principal virtude o fato de que esse processo normalmente já era do conhecimento do sócio ao se retirar, e, por certo, envolve dívida antiga que ele próprio contraiu. Ainda que se imagine que o processo tenha começado depois de sua saída, teve rito acelerado e gerou uma execução em apenas um ano ou um ano e meio, também é válida a presunção de que a dívida era conhecida e contemporânea. Em muitos casos, o valor da transação comercial nem terminou de ser pago e é provável que parte do crédito do sócio alienante seja utilizada para saldar a pendência.

O maior defeito da hipótese (b) é similar ao entrave encontrado na hipótese (a): a longa jornada que pode acontecer entre a citação da fase de execução e a concretização da penhora. Esse assunto não deve ser negligenciado. Explica-se.

Se o Oficial de Justiça se depara com a empresa fechada e lavra certidão negativa, ou mesmo que consiga citar o réu, mas não encontra bens hábeis à penhora, tem início um périplo que muito envergonha o processo judicial brasileiro, que pode levar dias, meses ou anos. O processo potencialmente aumentará a fila daqueles que ganharam, mas não levaram, ou seja, daqueles que conquistaram em juízo o reconhecimento de seus créditos e obtiveram título executivo judicial, mas não conseguiram, nem por esforço próprio, nem com auxílio dos instrumentos processuais, localizar patrimônio visível do devedor.

A busca por bens costuma durar anos. Envolve, via de regra, expedição de ofícios legais, atualmente substituídos amplamente por consulta aos meios eletrônicos de cadastros de informações, contas correntes, propriedade de veículos e de imóveis, além de diligências em endereços disponíveis em órgãos públicos.

Sucede, então, que, a folhas tantas, o magistrado pode optar pelo redirecionamento da execução em face do ex-sócio, ao argumento de que estão esgotadas as tentativas em face do patrimônio da pessoa jurídica e dos sócios presentes, quando eram passados cinco ou dez anos do início do processo ou cinco ou dez anos do início da própria fase de execução.

O ex-sócio é pego de surpresa com a visita do oficial de Justiça, ou, o que é mais comum, com o bloqueio de sua conta bancária (melhor: arresto a ser convertido em penhora, mediante oriundo de convênio entre a autoridade monetária e os órgãos judiciários). Novamente, não era essa a finalidade do art. 1003.

Resta, então, a hipótese (c), em que o prazo de dois anos é computado entre a retirada do sócio e a concretização da penhora, ou seja, a dívida é conhecida, o processo 
muito provavelmente é oriundo de sua época como líder do empreendimento, a fase de execução já devia estar em fase embrionária e a constrição patrimonial era esperada razoavelmente.

A penhora feita em apenas dois anos após a saída do sócio permite, também, que o preço da transação empresarial seja renegociado e que se verifique melhor a própria idoneidade do negócio jurídico - porque, note-se bem, a penhora feita sobre o patrimônio do ex-sócio significa que, em curto espaço de tempo, desapareceram todos os bens da pessoa jurídica e, simultaneamente, os bens das pessoas naturais cessionárias, o que está longe de ser razoável.

Há, seguramente, o risco de o ex-sócio se furtar ao recebimento da citação, omitir seus bens ou simplesmente ajudar o sócio atual a procrastinar o feito, como forma de empurrar o andamento processual e estourar o prazo de dois anos. Seria realmente muito cômodo que ele pudesse ficar na condução do processo. Mas para isso existem diversos remédios jurídicos conhecidos e de acesso relativamente simples, como as medidas cautelares - por exemplo, o arresto de bens do ex-sócio, como forma de acelerar a constrição patrimonial dentro do prazo de dois anos e, posteriormente, quando a execução estiver madura, fazer-se a conversão em penhora e ultimar-se a expropriação em hasta pública.

Deixando-se de lado a questão da forma de contagem do prazo, não se deve perder de vista que as expressões cedente e cessionário podem gerar algumas controvérsias, reforçadas pelo fato de que o art. 1.003 formalmente está inserido no capítulo das sociedades simples e não no capítulo das sociedades limitadas, que aparece no Código Civil de 2002 um pouco mais adiante.

Mas, na verdade, esse aparente descompasso não deve servir de obstáculo para a aplicação do prazo da responsabilidade solidária bienal. Enfrentemos a hermenêutica.

O Código Civil de 2002 adotou estilo próprio para cuidar das pessoas jurídicas de maneira geral, separando-as em sociedades personificadas, como as sociedades limitadas, e sociedades não personificadas, como a sociedade em conta de participação. O capítulo inicial das sociedades personificadas começa no art. 997 e discorre a respeito das sociedades simples. Ao depois, seguem-se diversos outros modelos societários - art. 1039, sociedade em nome coletivo; art. 1045, sociedade em comandita simples; art. 1052, sociedade limitada; art. 1088, sociedade anônima; art. 1090, sociedade comandita por ações; art. 1093, cooperativas - tendo todas elas como ponto comum a aplicação supletiva das disposições gerais atribuídas às sociedades simples.

Assim sendo, encontramos no art. 1053 previsão expressa no sentido de que às sociedades por quotas de responsabilidade limitada são aplicáveis as disposições gerais das sociedades simples, em caráter supletivo, e, como não há tratamento específico sobre o tema da co-responsabilidade dos sócios retirantes e dos sócios adquirentes, então é bastante tranquila a afirmação de que o art. 1003 encontra aplicação adequada também 
para as sociedades limitadas. Daí a felicidade do uso das expressões cedente e cessionário, pelo art. 1003, a fim de que possa ter uma amplitude maior do que se houvesse empregado expressões reducionistas, como quotista ou acionista.

É bem verdade que o art. 1053, parágrafo único, autoriza o contrato social da sociedade limitada a prever a aplicação subsidiária das normas que regem as sociedades anônimas, mas não parece que isso seria obstáculo intransponível para a responsabilidade solidária à luz do art. 1003, dado que as normas das sociedades anônimas, por seu turno, não oferecem dispositivo análogo, evitando-se, assim, a rota de colisão.

Há, ainda, o terceiro tema de estudo do art. 1003, representando pela locução "obrigações que tinha como sócio".

O art. 1003 teve o cuidado e o bom senso de não envolver o ex-sócio em pendências provocadas ou agravadas pelos adquirentes do estabelecimento. Não seria mesmo razoável que se pensasse em sentido contrário, pois o objetivo precípuo da norma é proteger os credores para que o devedor não se safe de sua obrigação sob o singelo argumento de ter alienado o empreendimento no meio da crise.

Ora, se a dívida foi contraída de modo superveniente, nem mesmo as técnicas de contagem de prazo, nas hipóteses acima denominadas de a, b e c, fariam sentido, pois se estaria tirando proveito da contagem dos dois anos para retroagir a responsabilidade por dívida futura.

Aliás, essa preocupação do legislador, em fixar a responsabilidade solidária apenas em caso de dívida antiga, reforça ainda mais a hipótese c, porque, como já sustentando, o prazo de dois anos computado entre a retirada do sócio e a concretização da penhora trabalhista faz supor que a dívida seja realmente antiga e conhecida de todos.

Nada obstante a complexidade dos três temas acima expostos - forma de contagem dos dois anos de responsabilidade solidária, intelecção das expressões cedente e cessionário e significado das obrigações pretéritas - o núcleo central da responsabilidade do ex-sócio reside, definitivamente, no direito ao contraditório e à ampla defesa.

De nada adiantam os esforços para se afinar a contagem do prazo, o conceito de cedente e o significado das dívidas antigas, se o sujeito é pego de surpresa e tem seu patrimônio atingido sem que nem ao menos soubesse da própria existência da ação judicial.

Como fomentar o contraditório à figura do ex-sócio é o tema de concentração do próximo tópico. 
4. Conclusões acerca da indispensabilidade do exercício do contraditório e da ampla defesa para o ex-sócio

Algumas providências básicas devem ser tomadas pelo processo do trabalho em caso de redirecionamento da execução na pessoa do ex-sócio, qualquer que seja o entendimento adotado acerca da contagem do prazo de dois anos.

Uma providência singela e que, na verdade, nem ao menos é jurídica, corresponde à anotação do nome do ex-sócio na capa dos autos - forma antiga de se dizer anotação do nome do ex-sócio no sistema informatizado que cadastra os processos -, de sorte que seja dada a maior publicidade a sua inserção como réu num processo trabalhista.

Como exemplo concreto de consequências dessa afirmação, é suficiente lembrar o exemplo do adquirente de um apartamento de uma pessoa física que apresentou todas as certidões negativas solicitadas, mas que era ré numa ação trabalhista, pelo procedimento da desconsideração da personalidade jurídica, mas sem publicidade do ato. Há jurisprudência dos tribunais superiores no sentido de que, se a Justiça do Trabalho errou ao emitir certidão negativa de pessoa física ocupante de pólo passivo em execução, o terceiro de boa-fé não pode ser prejudicado e o bem alienado não pode ser alcançado mais pela execução, jogando-se por terra a declaração de fraude à execução.

A providência da anotação na capa dos autos e no sistema informatizado do nome do sócio atingido pela execução consta, dentre outras normativas, da recomendação da Consolidação das Normas da Corregedoria Geral da Justiça do Trabalho, de 20 de abril de 2006, especialmente seu art. 52.13

Providência altamente relevante é proporcionar o direito ao contraditório e á ampla defesa.

Deve-se ter em mente que o redirecionamento da execução tanto pode capturar o patrimônio de um ex-sócio malicioso, que alienou a pessoa jurídica quando o barco naufragava, quanto o patrimônio de um ex-sócio zeloso, que tomou as cautelas necessárias para a alienação do empreendimento, deixou-o livre de dívidas e foi pego de surpresa com a falta de habilidade ou de prudência dos novos proprietários.

Uma ideia é equiparar a inclusão do ex-sócio como um novo réu, quase como uma intervenção de terceiro, que pega o processo do jeito em que se encontra -

13 Art. 52: "Os Corregedores dos Tribunais Regionais do Trabalho devem determinar aos Juízes da Execução que, ao entenderem pela aplicação da teoria da desconsideração da personalidade jurídica, chamando os sócios a responder pela execução trabalhista, adotem as seguintes medidas: I - determinar a reautuação para que conste o nome das pessoas naturais que passaram a responder pelo débito trabalhista; II - comunicar, imediatamente, ao setor competente pela expedição de certidões na Justiça do Trabalho, para a devida inscrição dos sócios no cadastro das pessoas com reclamações ou execuções trabalhistas; III - determinar ao setor competente que se abstenha de fornecer às referidas pessoas naturais certidão negativa, na Justiça do Trabalho; IV - determinar ao setor competente que, uma vez comprovada a inexistência de responsabilidade desses sócios, seja imediatamente cancelada a inscrição". 
ou seja, não se deve chegar ao exagero de reabrir prazo recursal já superado ou de se refazer o cálculo de liquidação, por cujo contraditório responde quem estava à frente do empreendimento à época -, mas que ao mesmo tempo tem o direito de ser ouvido e de levantar argumentos relativos a sua posição de co-responsável.

Os argumentos podem variar desde a simples indicação de bens à penhora da pessoa jurídica, assunto muito próprio dos debates de responsabilidade subsidiária, dado o direito a que por primeiro sejam excutidos os bens do responsável principal, até argumentos concernentes a nulidade de citação e indicação de endereços atuais dos demais responsáveis. Afora isso, pode também haver interesse legítimo do ex-sócio em questionar a avaliação dos bens penhorados, a impenhorabilidade de determinados bens na forma do art. 649 da Consolidação das Leis do Trabalho e os procedimentos convergentes à hasta pública.

Por conseguinte, o juiz deve priorizar a inserção do ex-sócio mediante expedição de mandado de citação, penhora e avaliação, ou seja, a pessoa natural deve ser preferencialmente citada, como um alerta de que uma execução trabalhista penderá contra seu patrimônio, conferindo-se o conhecido prazo de 48 horas para indicação de bens à penhora ou depósito garantidor da dívida. E, o que é ainda mais importante, após a efetivação da garantia, abrem-se os cinco dias de prazo para a apresentação dos embargos à execução, tudo na forma do art. 884 da Consolidação das Leis do Trabalho.

Evidentemente que a matéria dos embargos à execução estará limitada aos assuntos supervenientes e não mais aos cálculos de liquidação. Como se sabe, os embargos à execução trabalhista abarcam tanto a oportunidade para rediscussão dos cálculos de liquidação, ressalvada a preclusão a que se refere o art. 879, par. $2^{\circ}$, da CLT, como também a oportunidade para questionamentos sobre a citação, a penhora, a avaliação, o depósito e, em alguns casos, os editais de praça e leilão.

No caso dos embargos à alienação, previstos no art. 736 do Código de Processo Civil e aceitos pela jurisprudência do Tribunal Superior do Trabalho para o processo trabalhista, e no caso de embargos específicos sobre a realização de uma penhora indevida, como bem de família ou outro bem impenhorável, admite-se o uso dos embargos, mas com matéria restrita ao assunto específico.

Enquanto os embargos à execução do art. 884 da Consolidação das Leis do Trabalho apresentam vocação para a cognição plenária, os embargos supervenientes, também chamados de embargos de segundo grau ou de segunda geração, ostentam cognição limitada, o que já é suficiente em muitos casos para servir de canal de comunicação entre o ex-sócio e o magistrado.

Ao revés, não parece razoável o entendimento de se fazer a penhora direta sobre os bens do ex-sócio - tanto pior: o bloqueio das contas bancárias - sem que ele nem ao menos saiba da existência do processo. Isso pode ser feito em caso de empresas integrantes de grupo econômico, quando se adota o entendimento de que o grupo compõe 
um empregador único e, por presunção, uma empresa deveria comunicar à outra sobre a existência de um processo em curso, ou, ao menos, imagina-se que uma empresa tenha acesso à escrita contábil e ao passivo trabalhista da outra. Mas essa premissa, que já é sofrível para os grupos econômicos, não se sustenta no caso do ex-sócio, que efetivamente se retirou da administração e do convívio da sociedade, não dispondo de informações sobre a existência ou sobre o estágio do processo judicial.

Argumenta-se que a penhora pode ser feita diretamente sobre o patrimônio do ex-sócio, porque existe a responsabilidade solidária do artigo 1003 e porque o direito de defesa já foi exercido pela pessoa jurídica por ele integrada outrora. No entanto, esse entendimento se assenta sobre a falsa premissa de que pessoa jurídica, sócio e ex-sócio comporiam um único ente, uma única unidade, o que está longe de ser racional. Eles compõem feixes de interesse distintos e, em muitos casos, antagônicos.

Mal comparando, a história se aproxima da tentativa de se executar o tomador de serviços sem que ele tenha sido trazido ao processo na fase de conhecimento, sem que tenha sido condenado à luz da Súmula 331 e sem que ele conste do título executivo judicial, tese adotada em alguns regionais, mas que não encontrou abrigo na jurisprudência do Tribunal Superior do Trabalho. ${ }^{14}$

São Paulo, 9 de maio de 2011.

\section{Referências}

BENETI, Sidnei Agostinho. Desconsideração da sociedade e legitimidade ad causam: esboço de sistematização. In: Aspectos polêmicos e atuais sobre os terceiros no processo civil (e assuntos afins). DIDIER JUNIOR, Fredie; WAMBIER, Teresa Arruda Alvim (Org.). São Paulo: Revista dos Tribunais, 2004. p. 1.005-1.034.

BULGARELli, Waldirio. Direitos dos grupos e a concentração de empresas. São Paulo: Universitária de Direito, 1975.

BUSNELLI, Francesco Donato. La cosa giudicata nelle obbligazioni solidali. Rivista trimestrale di diritto e procedura civile. Milano: Giuffrè Editore, 1974. v. 28. n. 2. p. 393-440.

COMPARATO, Fábio Konder. A poder de controle na sociedade anônima. 3. ed. Rio de Janeiro: Forense, 1983.

DALLARI, Adilson Abreu. Apresentação de propostas por empresas pertencentes a um mesmo grupo econômico. Revista trimestral de direito público, São Paulo, n. 34, p. 5-12, 2001.

14 Verificar, por exemplo, o debate havido em fevereiro de 2011 no julgamento do Recurso de Revista 110940.19.2005.5.10.0013. 
FERREIRA, Luiz Eduardo Martins. Desconsideração da personalidade jurídica: uso e abuso. Revista da Escola Nacional da Magistratura, Brasília, v. 2, n. 3, p. 129-132, abr. 2007.

FRANCO, Vera Helena de Mello. Particularidades da "affectio societatis" no grupo econômico. Revista de Direito Mercantil, Industrial, Econômico e Financeiro, São Paulo, v.32, n.89, p.47-55, jan-mar. 1993.

LEDOULX, J. de. Contribution à l'étude des groupements d'interet economique. Revue Trimestrielle de Droit Commercial, Paris, n.22, p.1-15, 1969.

MAGANO, Octavio Bueno. Os grupos de empresas no direito do trabalho. São Paulo: Revista dos Tribunais, 1979.

MARIANI, Irineu. Responsabilidade civil dos sócios e dos administradores de sociedades empresárias (à luz do novo Código Civil). Revista dos Tribunais, São Paulo, v. 94, n. 834, p. 58-73, abr. 2005.

MARTINS FILHO, Ives Gandra da Silva. A responsabilidade solidária dos sócios ou administradores ante as dívidas trabalhistas da sociedade. In: SILVESTRE, Rita Maria; NASCIMENTO, Amauri Mascaro (Org.). Os novos paradigmas do direito do trabalho: homenagem a Valentin Carrion. São Paulo: Saraiva, 2001. p. 449-458.

MELLO, Rogério Licastro Torres de. A responsabilidade executiva secundária e a administração pública. Revista do advogado, São Paulo, v. XXVI, n. 88, p. 173-186, nov. 2006.

PÁDUA, José Elias Alvarenga de. Responsabilidade patrimonial dos sócios e dos eventuais exsócios pelas obrigações trabalhistas contraídas pela sociedade. Revista de Direito Mercantil, Industrial, Econômico e Financeiro, São Paulo, v. XLVI, n. 148, p. 59-87, out. 2007.

REQUIÃO, Rubens. Abuso de direito e fraude através da personalidade jurídica. In: Aspectos modernos de direito comercial: estudos e pareceres. São Paulo: Saraiva, 1977.

. Abuso de direito e fraude através da personalidade jurídica. Revista dos Tribunais, São Paulo, v. 58, n. 410, p.12-24, dez. 1969. Revista dos Tribunais, São Paulo, v. 91, n. 803, p. 751-764, set. 2002.

SANCHES, Sydney. Conseqüências da não denunciação da lide. Revista de jurisprudência do Tribunal de Justiça do Estado de São Paulo, São Paulo, p. 13-38, 1977.

. Denunciação da lide no direito processual civil brasileiro. São Paulo: Revista dos Tribunais, 1984.

SARAIVA, Renato. Curso de direito processual do trabalho. São Paulo: Método, 2005. p. 545.

SILVA, Homero Batista Mateus da. Estudo crítico da prescrição trabalhista. São Paulo: Ltr, 2004.

TADDEI, Marcelo Gazzi. O desafio da manutenção do sucesso da sociedade limitada na vigência do novo Código Civil. Jus Navigandi. Disponível em: <http://jus2.uol.com.br/doutrina/texto. asp?id=5106>. Acesso em: 4 mai. 2011. 
TEIXEIRA FILHO, Manoel Antonio. Execução no processo do trabalho. 3. ed. São Paulo: Ltr, 1992.

THEODORO JUNIOR, Humberto. Os embargos do devedor após as reformas do CPC efetuadas pelas Leis ns. 11.232 e 11.382. Revista do advogado, São Paulo, v. XXVII, n. 92, p. 89-108, jul. 2007.

VERÇOSA, Haroldo Malheiros Duclerc. O direito e a terceirização da economia. Revista dos Tribunais, São Paulo, v. 82, n. 688, p. 27-37, fev. 1993.

XAVIER, José Tadeu Neves. A teoria da desconsideração da pessoa jurídica no novo Código Civil. Revista Forense, Rio de Janeiro, a. 101, v. 379, p. 143-155. 